Academic Platform Journal of Engineering and Science

\title{
Standart Platin Direnç Termometrelerin Suyun Üçlü Noktası Hücresinde Kalibrasyonu ve Ölçüm Belirsizliği Hesabı
}

\author{
Fatma Melda Patan Alper \\ Yeditepe Üniversitesi, Fizik Bölümü, Ataşehir/İstanbul, \\ Araştırma Makalesi \\ Geliş Tarihi: 07.01.2020 \\ Kabul Tarihi: 06.05.2020
}

$\ddot{O} z$

Bu çalışmada direnç termometrelerin kalibrasyonların da ve kontrollerinde kullanılan suyun üçlü noktası hücresinin hazırlanması ve ölçüm belirsizliğinin hesaplanmasına ilişkin detaylı bilgi verilmiştir. Suyun üçlü noktası hücresi Yeditepe Üniversitesi Fizik Bölümü Metroloji ve Kalibrasyon Laboratuvarında (YUKAL) özel olarak tasarlanarak üretilmiştir. Hücrenin hazırlanması aşamasında katı $\mathrm{CO}_{2}$ kullanılarak buz tabakası elde edilmiştir. Katı $\mathrm{CO}_{2}$ yöntemiyle 15 dakikalık sürede hücre içerisinde katı, sıvı ve gaz fazlarının aynı anda elde edildiği bu yöntemle yapılan ölçümler analiz edilerek ölçüm belirsizliği bütçesi oluşturulmuştur.

Anahtar Kelimeler: Suyun Üçlü Noktası Hücresi, Kelvin, ITS-90, Direnç Termometre

\section{Calibration of Standard Platinum Resistance Thermometers in Triple Point of Water Cell and Evaluation of Measurement Uncertainty}

\author{
Melda Patan Alper \\ Yeditepe University, Department of Physics, Ataşehir/İstanbul
}

\begin{abstract}
In this study, detailed information about the preparation of triple point of water cell used in the calibration and control of resistance thermometers and calculation of measurement uncertainty is given. The triple point of water cell was designed and produced in Yeditepe University Physics Department Metrology and Calibration Laboratory (YUKAL). In the preparation of the cell, ice mantle was obtained using solid $\mathrm{CO}_{2}$. The measurement uncertainty budget was evaluated by analyzing the solid, liquid and gas phases in the cell at the same time with the solid $\mathrm{CO}_{2}$ method within 15 minutes.
\end{abstract}

Keywords: Triple Point of Water Cell, Kelvin, ITS-90

\section{GÍRIŞ}

Suyun üçlü noktası (SÜN) sıcaklığı; suyun üç fazının katı, sıv1 ve gaz termal dengede bulunduğu sicaklıktır. ITS-90 ölçeğine göre bu sıcaklık $0.01{ }^{\circ} \mathrm{C}$ olarak tanımlanmış olsa da Kelvin (K) Termodinamik Sıcaklık Ölçeğine göre ise 273.16 K olarak kabul edilmiştir. SÜN, 1990 Uluslararası Sicaklık Ölçeği (ITS-90) ve Kelvin Termodinamik Sicaklık Ölçeğinde tanımlanmış sabit noktalarından biridir [1]. Uluslararası yedi temel birimden biri olan Kelvin'in tanımı, suyun üçlü noktası mutlak (termodinamik) sıcaklığının 1/273.16's1 olarak belirlenmiştir [2]. SÜN hücresi silindirik borosilikat cam tüpün, yüksek saflıkta, gazsız ve izotropik bileşime sahip suyla doldurulmasıyla üretilir.
SÜN hücreleri, ITS-90 uluslararası sıcaklık ölçeğiyle uyumlu direnç termometrelerin (SPRT, PRT, IPRT) kalibrasyonunda ve/veya kontrollerinin gerçekleşmesinde kullanılır. Platin direnç termometreler yüksek hassasiyet ve doğrulukları sebebiyle çok tercih edilen termometrelerdir, bu sebeple kalibrasyonlarının ve ara kontrollerinin birincil seviye standartlarla gerçekleşmesi önemlidir [3,4].

SÜN hücresinde gerçekleşecek ölçümlerin doğruluğu pek çok parametreye bağlıdır. Bunlardan en önemlisi hücrenin imalatıdır. YUKAL'da özel tekniklerle üretimi gerçekleşen suyun üçlü noktası hücresi borosilikat cam tüplerden imal edilmiştir. İmalat aşaması, bu tüplerin sızdırma ve gerilim etkisinin azaltılması için tavlanmasıyla başlar, ardından hücreler kimyasal yöntemlerle temizlenerek ölçümleri

*Sorumlu Yazar: Yeditepe Üniversitesi, Fen-Edebiyat Fakültesi, Fizik Bölümü, İstanbul, Türkiye, mpatan@yeditepe.edu.tr, +90 $2165780000 / 1688$ 
etkileyebilecek kirlilikten arındırılır [5,6]. İçerik olarak analiz edilmiş distile su hücreye eklenir ve içerisinde hava kalmayacak şekilde kapatılır. Kullanılan saf su, izotop oranı okyanus suyuna yakın nitelikte, suyu özel yöntemlerle birkaç kez distile eden cihazlardan elde edilir. İzotop oranının ölçümlere doğrudan etkisi olması ölçüm belirsizliğini de etkiler $[7,8,9]$. SÜN hücresinin uzun yıllar kullanılması, ölçümlerin kararlı ve tekrarlanabilir olması hücre içerisinde kullanılan suyun saflığı ve kalitesine bağlıdır. Yaklaşık 500 $\mathrm{cm}^{3}$ saf su ile doldurulan hücreler daralan kısımlarından alevle mühürlenerek kapatılır [5]. SÜN hücrelerinin ölçüm için hazırlanması aşamasında farklı yöntemler kullanılabilir. Soğuk daldırma çubuğu, katı $\mathrm{CO}_{2}$ ve sıvı nitrojen yöntemi literatürde yaygın olarak kullanılan yöntemler arasındadır. $[5,9,10,11,12]$

\section{2. ÖLÇÜMLER}

\subsection{Cihazlar}

$\mathrm{Bu}$ araştırmada YUKAL üretimi 02/2010 seri numaralı 50 mm çaplı 330 mm uzunluğunda SÜN hücresi kullanılmıştır. Hücre Fluke marka 7341 model BOB361 seri numaralı alkol banyosunda muhafaza edilmiştir. Ölçümü gerçekleşecek test termometresi olarak Hart Scientific marka 5681 model 1432 seri numaralı kuartz kılıflı standart platin direnç termometre (SPRT) tercih edilmiştir. Termometreden alınan veriler Fluke marka 1594A model B11053 seri numaralı direnç köprüsü (dijital termometre) vasitasıyla sayısal veriye dönüştürülür.

\subsection{Metot}

SÜN hücresi, silindirik borosilikat cam tüpten üretilmiştir. SÜN hücresi ile doğruluğu yüksek, kararlı ve tekrar üretilebilir ölçümler yapabilmek için kullanılan suyun saflığ ve kalitesi dikkat edilmesi gereken en önemli parametredir. Hücre ilk aşamada kimyasal yöntemlerle temizlenerek özel yöntemlerle dinlendirilmiştir. Özel tasarım bu hücrenin içine iki kez damıtılmış yüksek saflıkta su konularak hava almadan kapatılmıştır. Hücre kapatıldıktan sonra içerisine herhangi bir maddenin girme riski yoktur. Hücrenin üretiminden sonraki aşama, ölçümler için hücrenin hazırlanması aşamasıdır. Ölçümlerde hızlı ve güvenli olması sebebiyle katı $\mathrm{CO}_{2}$ yöntemi kullanılmıştır. SÜN hücresinin içindeki termometrenin daldırıldığı tüp toz bırakmayacak bir çubuğa sarılı bir bez ile iyice temizlenerek kurutulur. Temizleme işlemin ardından, ölçümlerde kullanılacak SÜN hücresi, sıcaklık değeri yaklaşık $0.001{ }^{\circ} \mathrm{C}$ 'ye ayarlanmış, SÜN muhafaza alkol banyosu içine konarak, iki saat ön soğutma işlemine tabi tutulur. Yaklaşık $1 \mathrm{~kg}$ katı $\mathrm{CO}_{2}$, çekiç yardımıyla çok ufak parçalar haline getirilir (örneğin toz şekeri gibi). Ufalanmış katı $\mathrm{CO}_{2} \mathrm{SÜN}$ hücresi içerisine metal bir kaşık ile doldurulur (eklenen katı $\mathrm{CO}_{2}$ seviyesinin hücre içindeki su seviyesini geçmemesine dikkat edilir. Katı $\mathrm{CO}_{2}$ 'nin SÜN hücresi içinde homojen (hava boşluklarının kalmaması) olarak dağılması ve $\mathrm{CO}_{2}$ miktarının belirlenen seviyede kalması önemlidir. Bunun için SÜN hücresine parmak uçlarıyla yavaşça vurulur ve $\mathrm{CO}_{2}$ 'nin hücre içerisinde homojen olarak dağılması sağlanır. Bazen eklenen katı $\mathrm{CO}_{2}$ 'nin içindeki kirliliklerin oluşturabileceği safsızlıklar, SÜN hücresi içinde bir gri renkli kirlilik tabakası oluşturabilir. Eğer bu tabaka oluşur ise, SÜN hücresindeki 1S1 iletkenliğini azalacağından, bu kirlilik tabakası hücrenin çok dikkatli bir şekilde ters çevrilmesi ile hücre içinden dışarı atılabilir. SÜN hücrenin hazırlanış esnasında oda sıcaklığında sürekli ısınmasından dolayı hücre içinde oluşan buz tabakası homojen olmayabilir. Bunu önlemek için buz tabakası oluşturma esnasında hücre zaman zaman soğutulmak üzere SÜN muhafaza alkol banyosu geri konur.

Hücre içerisindeki $\mathrm{CO}_{2}$ ile su seviyesinin aynı olması gerekir. $\mathrm{CO}_{2}$ ve su seviyesinin eşit olmaması durumunda hücrenin üst kısmında buzlanma (buz köprüsü) oluşabilir. Bu durum SÜN'ün kırılmasına sebep olabilir. Buz köprüsü oluşması halinde, bu ince tabakanın etrafına başparmak ve orta parmaklar sarılarak vücut isısıyla, oluşan buz köprüsü eritilir. SÜN hücresi içinde oluşturulan buz tabakasının kalınlığı 6-8 mm arasında olduğunda katı $\mathrm{CO}_{2}$ eklenmesi durdurulur. Işığıın kırılmasından dolayı, buz tabakası kalınlığının ne kadar olduğunu dışarıdan bakarak gözlenmesi güçtür. Oluşan buzun kalınlığını doğru gözlemleyebilmek için, hücre su dolu beher içerisine daldırılır ve 1şığın kırılmasından kaynaklanan yanılgı ortadan kaldırılarak buz kalınlığı doğru gözlenmiş olur. Buz kalınlığının fazla olması ve bu katı fazın büyümeye devam etmesi hücrenin kırılmasına sebep olabilir. Katı faz yeterli kalınlığa ulaştığında (buz hücre iç duvarından birkaç mm uzak olmalı) hücre içinde geriye kalan katı $\mathrm{CO}_{2}$, hücreyi yavaşça eğerek dışarı atılır. SÜN hücresinin içine buzda soğutulmuş su (termal temas sıvısı) eklenir, eklenen su seviyesi; hücrenin içerisinde termometre var iken, hücre içindeki su seviyesini geçmemelidir. Hücre içerisindeki katı fazın daha kararlı ve yapısal olarak uygun hale gelmesi için, hücre 24 saat alkol banyosunda bekletilir [13]. SÜN ölçüme başlanmadan önce, metal bir çubuk hücreye daldırılarak birkaç dakika bekletilir katı fazın biraz eriyerek cam tüpten ayrılması sağlanır. Hücre avuç içerisinde yavaşça döndürülür, bu döndürme işlemiyle katı fazında termometrenin daldırıldığı tüpün etrafında döndüğü görülmelidir. Eğer buz tabakası dönmüyor ise oda sıcaklığındaki metal çubuk tekrar 30 saniyeliğine hücreye daldırılarak işlem tekrar edilir. Tüm bu işlemlerden sonra Şekil 1'de görüldüğü gibi, hücre içerisinde 3 faz elde edilmiş olur.

Buz kalınlığını koruyarak hücreyi birkaç hafta kullanabilmek ve termal radyasyonu önlemek amaciyla hücre, sıcaklığı yaklaşık $0.001{ }^{\circ} \mathrm{C}$ olan alkol banyosunda 1 şı almayacak şekilde muhafaza edilerek ölçüm işlemlerine başlanır. Hücre banyonun içine konulduğunda banyonun dengeye gelmiş olması önemlidir, aksi takdirde banyonun daha sıcak olması hücre içerisinde buz tabakasının erimesine, banyonun daha soğuk olması ise buz tabakasının büyümeye devam ederek kırılmasına sebep olabilir. Ölçüm düzeneği Şekil 2'de görülmektedir. 


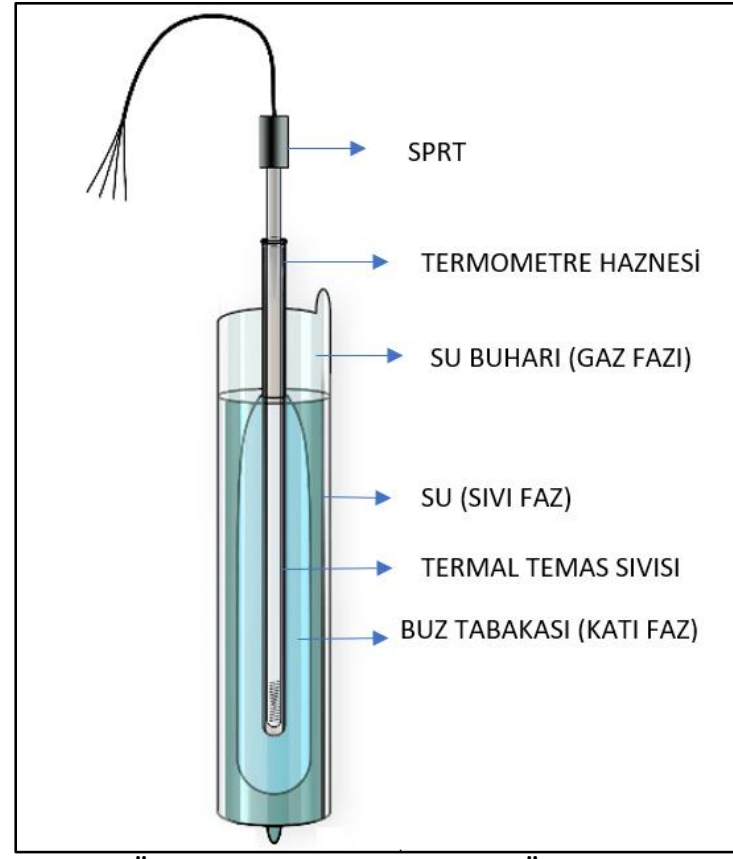

Şekil 1. Ölçümler için hazırlanmış SÜN hücresi

Kalibrasyonu gerçekleşecek olan SPRT, SÜN hücresi içerisine konulmadan önce alkol banyosuna daldırılarak ortam sıcaklığından daha düşük bir sıcaklığa gelmesi ve hücrenin içerisine girdiğinde buz tabakasını eritmesi engellenmiş olur. Termometre hücre içerisine dikkatlice yerleştirilmelidir. İdeal bir ölçüm için yukarıda bahsedildiği gibi hücre hazırlandıktan sonra ölçümlere kadar 24 saat banyo içerisinde bekletilmesi önerilir. $\mathrm{Bu}$ süre katı fazın daha kararlı hale gelmesini, buzun üzerindeki gerilimin azalmasını sağlayacaktır. Ölçümlere başlamadan önce termometre sensörü (SPRT) dijital bir termometreye bağlanır, dijital termometre SPRT'den elde edilen direnç değerini sıcaklık değerine dönüştürür. Ölçümler 30 saniye ara ile seri şekilde gerçekleşir, en az 10 ölçüm alınır. Ölçüm akımı olarak $1 \mathrm{~mA}$ kullanılır.

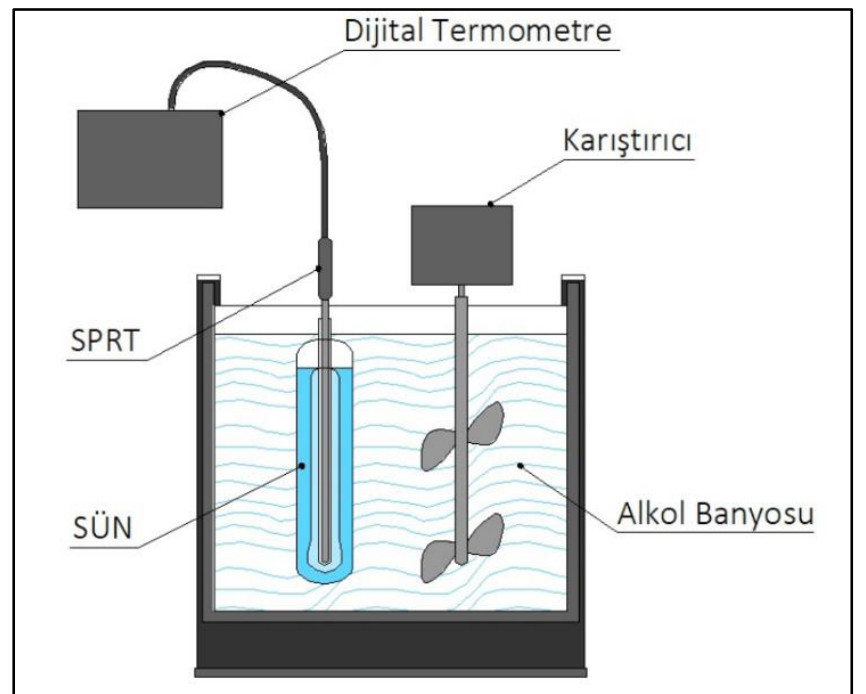

Şekil 2. Banyo içerisine yerleştirilmiș SÜN hücresi ile SPRT kalibrasyon düzeneği

\section{3. Ölçüm Belirsizliği}

Ölçüm sonucunun belirsizliği, ölçülen cihazın kesin değerinin bilinmesindeki eksikliği yansıtır. Fark edilen sistematik hataların düzeltilmesinden sonraki ölçüm sonucu, rastgele hatalardan dolayı ortaya çıkan belirsizlikten dolayı hala sadece bir tahminden ibarettir. Gerçek değere en yakın sonucu elde etmek ölçümlerde belirsizliğe etkisi olan hata kaynaklarının etkin şekilde değerlendirilmesiyle mümkündür. $\mathrm{Bu}$ örnekte belirsizlik hesabı EA-4/02 rehber dokümanına uygun olarak yapılmıştır [14,15]. SÜN hücresinde gerçekleşen kalibrasyon işleminde hem hücreden hem de referans termometreden kaynaklanan etkilerin belirsizlik bütçesine eklenmesi gerekmektedir. $\mathrm{Bu}$ araştırmada A ve B tipi belirsizlik parametreleri standartlara uygun analiz edilerek uygun istatistiksel yöntemlerle genişletilmiş belirsizlik değeri \%95 güvenilirlik seviyesiyle hesaplanmıştır [5,14]. Ölçümlerde hesaba katılan tüm belirsizlik parametreleri Tablo 1'de verilmiștir. Tüm veriler laboratuvarda gerçekleştirilen ölçümler sonucu elde edilmiştir. Tahmini belirsizlik değerleri için istatistiksel dağılım türleri tespit edilerek tüm dağılımlar normal dağılıma çevrilerek standart belirsizlik değerleri bulunmuştur. Belirsizlik hesabında referans sıcaklık değeri için model fonksiyonu aşağıdaki şekilde tanımlanmıştır $[14,15]$

$\mathrm{t}_{\mathrm{x}}=\mathrm{t}_{\mathrm{s}}\left[\delta \mathrm{t}_{\mathrm{RU}}+\mathrm{C}_{\mathrm{S}} \cdot \delta \boldsymbol{\Omega}_{\mathrm{RG}}+\mathrm{C}_{\mathrm{S}^{\bullet}} \delta \boldsymbol{\Omega}_{\mathrm{SH}}+\delta \mathrm{t}_{\mathrm{IC}}+\mathrm{C}_{\mathrm{S}} \cdot \delta \boldsymbol{\Omega}_{\mathrm{HB}}+\delta \mathrm{t}_{\mathrm{BS}}\right.$ $\left.\mathrm{C}_{S} \cdot \delta \Omega_{\mathrm{RR}}+\mathrm{C}_{S} \cdot \delta \Omega_{\mathrm{RT}}+\mathrm{C}_{S} \cdot \delta \Omega_{\mathrm{RE}}\right]$

$\mathbf{t}_{\mathrm{s}}=\quad$ Referans Termometreden Okunan Değer

$\mathbf{t}_{\mathbf{x}}=\quad$ Kalibre Edilen Termometreden Okunan Değer

$\boldsymbol{\delta} \mathbf{t}_{\mathbf{R U}}=$ Referans Hücre Sertifika Belirsizliği

$\boldsymbol{\delta} \boldsymbol{\Omega}_{\mathbf{R G}}=$ Direnç Köprüsünün Belirsizliği

$\boldsymbol{\delta} \boldsymbol{\Omega}_{\mathrm{SH}}=$ Self Heating Etkisi

$\boldsymbol{\delta} \mathbf{t}_{\mathbf{I C}}=$ İzotopic Kompozisyon Etkisi

$\boldsymbol{\delta} \boldsymbol{\Omega}_{\mathbf{H B}}=$ Hidrostatik Basınç Etkisi

$\boldsymbol{\delta} \mathbf{t}_{\mathbf{B S}}=$ Banyo Kararlılık ve Homonejitesi

$\boldsymbol{\delta} \boldsymbol{\Omega}_{\mathbf{R R}}=$ SPRT K1sa Dönem Kararlılık

$\boldsymbol{\delta} \boldsymbol{\Omega}_{\mathbf{R T}}=$ SPRT Tekrarüretilebilirlik

$\boldsymbol{\delta} \boldsymbol{\Omega}_{\mathbf{R E}}=$ SPRT Çözünürlük Değeri

$\mathrm{Cs}_{\mathbf{s}}=$ Hassasiyet Katsayısı

Hidrostatik Basınç Etkisinin ölçümlere olan etkisi hücre içerisine tam daldırılmasından kaynaklanmaktadır oysa ölçüm yapılması gereken nokta hücrenin en alt noktası yerine suyun üç fazının elde edildiği saf suyun hücre içerisindeki en yüksek noktasıdır, fakat SPRT'ler ile doğru ölçüm yapabilmek için termometrenin daldırma derinliği dikkate alınarak en alt noktada ölçüm yapılmalıdır, doğru noktada ölçüm yapılamaması basınç farkı kaynaklı hataya sebep olabilmektedir bu da hidrostatik basınç etkisi olarak hesaba katılmalıdır, bu değer hesaplanırken, termometrenin en uç noktasından direncin bittiği noktaya kadarki uzunluğun yarısı alınarak başlangıç noktası seçilir. Hücre içerisine konulan termometrenin direncinin tam orta noktasından, hücre içindeki sıvının bittiği noktaya kadarki kısım cetvelle ölçülür. Bu uzunluğun kaç dereceye denk geldiği hidrostatik basınç düzeltme değeri hesaba katılarak bulunur [5, 18]. 
(Örneğin $0.30 \mathrm{~m}$ ölçülmüş uzunluk için $0.3 \mathrm{~m}$ x $0.73 \mathrm{mK} / \mathrm{m}$ $=0.219 \mathrm{~m}^{\circ} \mathrm{C}$ ) Kalibrasyon aşamasında SPRT ile $10 \mathrm{sn}$ ara ile 10 ölçüm alınmıştır bu ölçümlerin standart sapması SPRT Kısa Dönem Kararlılık değeri olarak bütçeye eklenmiştir. SPRT Tekrar üretilebilirlik değeri için aynı ölçümler ikinci gün tekrar yapılmış ve iki ölçüm arasındaki fark hesaplanarak bulunmuştur. SPRT çözünürlük değeri termometrenin bağlandığı direnç köprüsünün çözünürlüğü alınarak hesaba katılmıştır.

Tablo 1. SÜN hücresinde SPRT termometre kalibrasyonu tahmini belirsizlik bütçesi hesabı

\begin{tabular}{|c|c|c|c|c|}
\hline Belirsizlik Bileșeni & $\begin{array}{c}\text { Tahmini } \\
\text { Belirsizlik }\end{array}$ & $\begin{array}{l}\text { İstatistiksel } \\
\text { Dağı̆lım }\end{array}$ & $\begin{array}{c}\text { Hassasiyet } \\
\text { Katsayısı } \\
\text { (Duyarhlık) }\end{array}$ & $\begin{array}{c}\text { Standart } \\
\text { Belirsizlik } \\
\left({ }^{\circ} \mathrm{C}\right)\end{array}$ \\
\hline $\begin{array}{l}\text { Referans Hücre } \\
\text { Belirsizliği }\end{array}$ & $0.0002^{\circ} \mathrm{C}$ & Normal & 1 & 0.0001 \\
\hline Köprü Belirsizlik & $0.000006 \Omega$ & Normal & $10^{\circ} \mathrm{C} / \Omega$ & 0.00003 \\
\hline Self Heating & $0.0000015 \Omega$ & Dikdörtgen & $10^{\circ} \mathrm{C} / \Omega$ & 8.67E-06 \\
\hline $\begin{array}{l}\text { Izotropik } \\
\text { Kompozisyon } \\
\text { Etkisi }\end{array}$ & $0.000010^{\circ} \mathrm{C}$ & Dikdörtgen & 1 & $5.780 \mathrm{E}-06$ \\
\hline $\begin{array}{l}\text { Hidrostatik Basınç } \\
\text { Etkisi }\end{array}$ & $\begin{array}{c}0.00000146 \\
\Omega\end{array}$ & Dikdörtgen & $10^{\circ} \mathrm{C} / \Omega$ & 8.439E-06 \\
\hline $\begin{array}{l}\text { Banyo Kararlulık ve } \\
\text { Homojenite }\end{array}$ & $0.003{ }^{\circ} \mathrm{C}$ & Dikdörtgen & 1 & 0.0017344 \\
\hline $\begin{array}{l}\text { SPRT KIsa Dönem } \\
\text { Kararlılık }\end{array}$ & $0.000006 \Omega$ & Normal & $10^{\circ} \mathrm{C} / \Omega$ & 0.00006 \\
\hline $\begin{array}{l}\text { SPRT } \\
\text { Tekrarüretilebilirlik }\end{array}$ & 13.0E-06 $\Omega$ & Dikdörtgen & $10{ }^{\circ} \mathrm{C} / \Omega$ & 0.0002249 \\
\hline SPRTÇözünürlük & $0.000001 \Omega$ & Dikdörtgen & $10^{\circ} \mathrm{C} / \Omega$ & $5.780 \mathrm{E}-06$ \\
\hline \multicolumn{4}{|c|}{ Standart Toplam Belirsizlik $=\mathrm{U}_{\mathrm{t}} \mathrm{v}\left(\mathrm{U}^{2} \mathrm{t}_{1}{ }^{2}+\mathrm{U}^{2} \mathrm{t}_{2}{ }^{2}+\mathrm{U}^{2} \mathrm{t}_{3}{ }^{2}+\mathrm{U} \delta \mathrm{t}_{4}{ }^{2}+\mathrm{U} \delta \mathrm{t}{ }^{2}+\mathrm{U} \delta \mathrm{t}_{6}{ }^{2}+\delta \mathrm{t}_{7}{ }^{2}\right.$} & 0.00175 \\
\hline \multicolumn{4}{|c|}{ Genişletilmiş Belirsizlik $=\mathrm{U}=\mathrm{kx} \mathrm{U}_{\mathrm{t}}=2 \times 0.00175$} & 0.0035 \\
\hline
\end{tabular}

\section{SONUÇ}

Yüksek metrolojik vasıflara sahip SPRT'lerin sıcaklık ölçümlerinde ve kalibrasyonlarında kullanımı gittikçe yaygınlaşmaktadır. $\mathrm{Bu}$ tür termometrelerin buz noktası yerine suyun üçlü noktası hücresinde kalibrasyonun ve kontrolünün gerçekleştirilmesi doğruluğu yüksek, belirsizliği düşük sonuçlar sağlamaktadır.

$\mathrm{Bu}$ çalışmada SÜN hücresi ile ölçümlerin gerçekleştirilmesine ve ölçüm belirsizlik hesabının yapılmasına ilişkin detaylı bilgi verilmiştir. Deneysel sonuçlar göstermektedir ki SPRT'lerin SÜN hücresinde kalibrasyonunda $\mathrm{k}=2 \% 95$ güvenilirlik seviyesiyle ölçüm belirsizliği $3.5 \mathrm{~m}^{\circ} \mathrm{C}$ olarak hesaplanmıştır.

\section{KAYNAKÇA}

[1] H. P. Thomas, The International Temperature Scale of 1990 (ITS-90), Metrologia, cilt 27, no. 1, 1990.

[2] T. J. Quinn, Temperature, Academic Press, 2013.

[3] T. D. McGee, Principles and Methods of Temperature Measurement, New York, United States: John Wiley \& Sons Inc, 1988.

[4] R. E. Bentley, Handbook of Temperature Measurement.: Volume 1, Temperature and Humidity Measurement, Springer Science \& Business Media, 1998.

[5] A. Peruzzi, E. Mendez-Lango, J. Zhang ve M. Kalemci, Guide to the Realization of the ITS-90 Triple Point of Water, Bureau International des Poids et Mesures, 2017

[6] A. Peruzzi, M. Dobre, J. v. Geel, A. Uytun, Kalemci, M. Kalemci, E. Uysal, G. Strouse ve Y. Nue, Effect of Impurities on Water Triple-Point Cells, International Journal of Thermophysics , no. 35, 1084-1096.

[7] G. T. Furukawa, B. W. Mangum ve G. F. Strouse, Effects of different methods of preparation of ice mantles of triple point of water cells on the temporal behaviour of the triplepoint temperatures, Metrologia, cilt 34, p. 215, 1997.

[8] J. V. Nicholas, T. . D. Dransfield ve D. R. White, Isotopic composition of water used for triple point of water cells, Metrologia, cilt 33, no. 3, 1996.

[9] D. R. White ve W. L. Tew , Improved Estimates of the Isotopic Correction Constants for the Triple Point of Water, International Journal of Thermophysics, no. 31, p. 1644 1653, 2010.

[10] G. T. Furukawa, B. W. Mangum ve G. F. Strouse, Effects of different methods of preparation of ice mantles of triple point of water cells on the temporal behaviour of the triple-point temperatures, Metrologia, cilt 34, p. 215, 1997.

[11] A. Peruzzi, M. Dobre, G. Strouse, J. Van Geel, Doping Experiments with Water Triple-Point Cells, Int J Thermophys (2011) 32:1553-1562

[12] K. N. Quelhas, · R. N. Teixeira, An Alternative Method for Manufacturing Water Triple-Point Cells, Int J Thermophys (2014) 35:1097-1108

[13] A. İnce, A. Kartal, Uluslararası Sicaklık Ölçeği 1990 (ITS-90)'nın Ulusal Metroloji Enstitüsünde (Ume) Gerçekleştirilmesi Ve Muhafazası, TMMOB II. Ulusal Ölçümbilim Kongresi Bildiriler Kitabı, 23 - 24 EKİM 1997, Eskişehir,

[14] EA-4/02 Evaluation of the Uncertainty of Measurement in Calibration, EA Laboratory Committee, 2013

[15] S. Armstrong, The Development of a Primary Laboratory for the Calibration of Standard Platinum Resistance Thermometers, AIP Conference Proceedings 684, 351 (2003)

[16] J.J. Connolly, R.E. Bentley, Platinum Resistance Thermometry, First Edition, NMI, 2004

[17] J. Tamba, M. Sakai, I. Kishimoto ve M. Ar, «Isotopic Correction of Water-Triple-Point Cells at NMIJ,» International Journal of Thermophysics , no. 29, 1749-1760. [18] V. Zuzek, J. Bojkovski, V. Batagelj, J. Drnovsek, SPRT Immersion Profiles in a TPW Cell with the Use of Metal Bushings, 9th International Temperature Symposium on Temperature - Its Measurement, 2013, 1552 